\title{
Ivana Bašić, Dokazivanje i odnos prema znanju u jeziku znanosti, Hrvatska sveučilišna naklada, Zagreb, 2020.
}

Predmet je ovog prikaza knjiga Dokazivanje i odnos prema znanju u jeziku znanosti autorice Ivane Bašić, objavljena u studenome 2020. godine u izdanju Hrvatske sveučilišne naklade. Dr. sc. Ivana Bašić viša je lektorica na Odsjeku za anglistiku Filozofskog fakulteta u Zagrebu, predsjednica Zagrebačkog ogranka Hrvatskog društva za primijenjenu lingvistiku te osnivačica strukovne udruge Hrvatskog društva sveučilišnih lektora s bogatim iskustvom u promoviranju filološke struke, koja je do sada objavila 4 udžbenika. U ovoj izvrsno koncipiranoj knjizi koja izrasta iz dugogodišnjeg istraživanja lingvističkog pojma dokaznosti (Bašić 2017) autorica se usredotočuje na analizu znanstvenog diskurza, odnosno jezičnih načina 'na koje govornik signalizira kako/odakle zna to što govori i kako procjenjuje to znanje' te 'kako se u znanstvenom diskurzu retorički konstruira uvjerljivost i vjerodostojnost'. Spajajući vješto tradicionalne gramatičke pristupe i suvremene kognitivno-lingvističke metode knjiga rasvjetljuje jezične strategije koje izvještavanje u znanosti čine uvjerljivijim te razlike u obrascima izvještavanja u različitim granama znanosti.

Tematika dokaznosti primjerena je suvremenom dobu koje intenzivno propituje različite vrste izvještavanja o stvarnosti, pri čemu je razvidno da niti znanstveni diskurz, sve dok i nastoji zadržati načela objektivnosti i transparentnosti u svojem stilu, nije lišen kulturno uvjetovanih procesa konstruiranja znanja pa i kulturne relativnosti koju oblikuju izrečeni i prešutni uzusi znanstvenih disciplina i hijerarhijski ustrojenih istraživačkih institucija. Kroz inovativnu metodu kontekstualizirane analize konvencionalizirane uporabe glagola izvješćivanja, poput pokazalo se da $x, y j e$ utvrdio da $z$, we argue, we suggest i sl., autorica daje uvid u uvriježene načine diskursnog oblikovanja znanja i sustavnu dinamiku strategije konstruiranja dokaznih značenja koja je prilagođena društvenom kontekstu kulture različitih znanstvenih disciplina i zajednica.

Knjiga je tiskana na 193 stranice koje su podijeljene u četiri tematski povezana poglavlja kojima prethodi »Predgovor«, a na kraju se nalazi »Završna riječ«, iscrpan popis konzultirane »Literature«, bilješka o autorici te »Kazalo pojmova«. Knjiga je namijenjena, prije svega, znanstvenicima koji žele osvijestiti tipične obrasce izvješćivanja vlastite discipline i upoznati se sa spoznajnim načelima dokaznosti u drugim disciplinama. Međutim, značajke sustavnosti pristupa temi dokaznosti, iscrpan popis relevantne literature, te jasnoća razglobljivanja epistemoloških, lingvističkih i društveno-kulturnih sastavnica postavlja ovu knjigu vrlo visoko na popis malobrojnih udžbenika za promicanje vještina znanstvenog pisanja radova, i to od preddiplomske razine naviše.

Autorica pomno prilazi vrlo složenom jezikoslovnom pitanju dokaznosti prikazujući njegovu slojevitost u četiri veća poglavlja. U prvom daje pregled temeljnih 
epistemoloških pitanja vezanih uz komunikacijska pravila i razumijevanje općenito, pri čemu osobitu pozornost posvećuje razradi dokaznosti kao tekstualno šire shvaćenog pojma kategorije evidencijalnosti koja obuhvaća gramatički kodirane i usustavljene načine izražavanja. Vraćajući nas na nezaobilazni sapirijanski jezikoslovni izvor rasprava o gramatičkim kategorijama, koji je obogaćen suvremenijim kognitivno-lingvističkim istraživanjima, autorica nas vješto izmješta iz okvira hrvatskog i sličnih jezika koji informacije o izvorima/metodama spoznaje iskazuju na razini leksičko-sintaktičkog inventara, uvodeći nas u širu perspektivu jezika među kojima se nalaze i oni koji imaju gramatikaliziranu kategoriju evidencijalnosti, i to već na razini gramatičkih nastavaka. Taj obzor jezične relativnosti, s jedne strane, otvara problematiku zanimljivih kulturno-pragmatičnih pitanja poput: komeje na razini gramatičkog koda potrebno razlučivati kategoriju znanja stečenog izravnim iskustvom, posredstvom drugih ili tek zaključivanjem? Radili se o jezičnoj zajednici egzotičnih govornika koji intenzivno njeguju epistemološke rasprave, ili taj podatak ima pragmatičnu vrijednost u kontekstu njihove eko-komunikacijske svakodnevice? Sve su to pitanja koja nas izlažu postojanju različitih mehanizama stjecanja znanja i dokaznosti u jezičnim sustavima. $S$ druge strane, navedena šira perspektiva odvodi nas još dublje u raspravu o temeljima jezične epistemologije, trovrsnim ishodima implicitnog dogovora govornika i slušatelja koji, prema Givónu (1982), mogu propozicije ne propitivati, uzeti sa relativnom sigurnošću ili sumnjičavo odbaciti. Izricanje stupnja sigurnosti dodatno je usložnjeno subjektivnošću spoznaje i govornikove procjene statusa znanja, njihova epistemičkog stava, dokazivanja i ograđivanja. Premreženost teorija, pristupa i pojmova autorica smisleno razvezuje jasnom strukturom i znalačkim dodirima spoznaja iz radova znanstvenika poput Ronalda W. Langackera, Elzbiete Tabakowske, Ilane Mushin, Elizabeth Closs Traugott, Eve Sweetser, Crystal Bybee, Alexandre Aikhenvald i Milene Žic Fuchs, sve odredom istaknutih kognitivno-kulturalnih lingvista. Nadalje, u nekoliko odjeljaka Bašić zahvaća i u rasutost evidencijalnosti po raznim podkategorijama jezičnog sustava glagolskih vremena, aspekata i modalnosti, pojašnjavajući kontinuum gramatike i pragmatike u konstruiranju dokaznih značenja i službu dokaznog obilježavanja iskaza u različitim jezicima. Sve su konstrukcije oprimjerene kroz različite jezike, a od navedenih spomenimo tek hrvatsku kombinaciju glagola percepcije čuti i vidjeti te zavisnih surečenica uvedenih veznicima da i kako koje Gnjatovići Matasović (2010) tumače kao opreku posredne i neposredne evidencijalnosti, kao u Čujem da dolazi nasuprot Čujem kako dolazi. Poglavlje završava razmatranjem različitih evidencijalnih gramatičkih oblika kao obilježja žanra i strategija uspostavljanja autoriteta pri izvješćivanju, što ujedno postavlja izvrsnu scenu za problematizaciju znanstvenog diskurza koje se dešava u drugom poglavlju.

Znanstveni diskurz određen je kao komunikacijski način kojim znanstvenici priopćavaju svoje spoznaje s ciljem da ih znanstvena zajednica 'ovjeri i prihvati kao legitimno znanje'. Usredotočujući se na horizontalnu akademsku komunikaciju između ravnopravnih kolega znanstvenika određene discipline, autorica problema- 
tizira strategije uvjeravanja ugrađene u diskurzne konvencije koje čine izgradnju znanja disciplina, ne zanemarujući hegemonijski utjecaj socijalno-ekonomskih sastavnica, često zapostavljen u lingvističkim priručnicima akademske komunikacije. Engleski jezik kao lingua franca, 'tržište' za koje se piše, financijeri istraživanja, pripadnost društveno-humanističkim mekim nasuprot tvrdim prirodnim i tehničkim znanstvenim područjima, sve to eksplicitno i implicitno utječe na stil komunikacije i retoričke preferencije. Navedene sastavnice autorica uklapa u razmatranje diskurznih funkcija visokog i niskog rizika. Stil visokog rizika uključuje eksplicitno izražavanje vlastitog mišljenja, primjerice uporabom ekskluzivnog 'ja', čime se znanstvenici izlažu potencijalnoj kritici i ugrožavanju obraza ali s željom da profitiraju stvaranjem aure prisutnosti, autentičnosti i autoriteta. Niskorizični stil komunicira spoznaje korištenjem inkluzivnog 'mi' i pozivanjem na opće uvriježene spoznaje ugrađujući se mekše u dinamiku suodnosa stvaranja znanstvenih tekstova i primjene načela uljudnosti. Bašić nadalje razmatra ograničenja osobnog stila znanstvenog pisanja i načina predstavljanja znanstvenih informacija kao vjerodostojnih u različitim znanstvenim zajednicama te daje sažetak epistemoloških postavki zajedničkih svim znanstvenim disciplinama i kulturama. Tu se objašnjava kognitivno-teorijska utemeljenost analize izraza izvješćivanja i glagola izvješćivanja kao pristupnih točaka širem enciklopedijskom znanju koje je ograničeno utjelovljenim datostima spoznaje ali društveno konvencionalizirano: "Naime, upravo odabirom različitih glagola izvješćivanja, koji svojim leksičko-gramatičkim osobitostima uvjetuju i ustroj ostatka rečenice, pisac znanstvenog rada kodira podatke o izvoru informacije, odnosu načinu spoznavanja informacije, ali i stavu prema informaciji koju prenosi«. (Bašić 2020:60)

Glavni dio trećeg poglavlja odnosi se na predstavljanje analize narativne forme izvješćivanja (engl. reporting) kao tipičnog načina prijenosa informacija u znanstvenom diskurzu. Objašnjava se uloga glagola izvješćivanja u jezičnom arsenalu diskursnih funkcija te njihov značaj u praksi integriranog i neintegriranog citiranja za profiliranje odabira dokaznih strategija. Nadalje, predstavljaju se značenjski i sintaktički tip analize glagola, pri čemu se značenjskom analizom glagoli kategoriziraju kao tekstni (primjerice state, write, underline), glagoli mišljenja (primjerice think, believe) ili istraživanja (primjerice find, demonstrate) (Thompson i Yiyun 1991), dok se sintaktičkom analizom izdvajaju obrasci, poput $S+V+T H A T$ ili BE VEBED ili IT IS $V E R B E D$ te konstrukcije određenih veza glagolskog vremena i vida. Odabirom stilova navođenja, glagola izvješćivanja i vještom kombinacijom gramatičkih sastavnica može se isti sadržaj prikazati u prilično različitom svjetlu. Primjerice, u iskazu Jones (1986) found that bacteria could not reproduce... ističe se specifičnost spoznaje integriranim načinom citiranja nasuprot naizgled općenitom neintegriranom iskazu Bacteria have been shown to be unable to reproduce... koji pasivom implicira njezinu uvriježenost i neupitnost.

Navedeni sadržaj prethodnih poglavlja uvodi nas pojmovno i teorijski spremne u četvrto poglavlje gdje se prikazuju rezultati analize korpusa 165 znanstvenih ra- 
dova, od čega 95 na engleskome i 70 na hrvatskome jeziku, promatrane kroz prizmu pojmovne kategorije dokaznosti. Metodološki uvjetovanim odabirom radova iz devet različitih disciplina, od računarstva, strojarstva, fizike, kemije, biomedicine i psihologije do sociologije, lingvistike i književnosti, autorica je stvorila uravnoteženi korpus za prikaz konvencionalizacije jezičnih načina izražavanja spoznaja, kako onih empirijski stečenih eksperimentalnim istraživanjima, tako i onih koje znatnije počivaju na argumentaciji. Usporedna analiza hrvatskih i engleskih članaka kontrastno prikazuje dokazne strategije u manjem nacionalnom i globalnom jeziku međunarodne znanstvene zajednice. Osobito je zanimljivo što ni hrvatski ni engleski nisu jezici u kojima je dokaznost obvezna gramatička kategorija pa se njihovi iskazi mogu uzeti kao primjeri pragmatičkih jezičnih strategija, odnosno njihovih specifičnih dokaznih i epistemičkih značenja. Analizom retoričkih sredstava, od izražavanja epistemološkog stava, preko perspektive izvješćivanja do evaluacijskih izraza ograđivanja i isticanja, autorica klasificira iskazivanje u tri tipa znanja: osobno spoznata, činjenična i ona preuzeta od autoriteta. Izbjegavajući reduktivni statistički pristup s potencijalno neprotumačivim podacima o čestotnosti izraza, autorica se odlučila za metodu kvalitativne analize s kognitivnolingvističkim pristupom tumačenju, usredotočujući se na predstavljanje relevantnih podataka o tipovima izraza s obzirom na pojedinu disciplinu te njihove implikacije. Svaki je tip konstruiranja znanja oprimjeren sa po stotinjak iskaza iz korpusa. Autorica u završnim odjeljcima sažima zaključke analize o tipovima znanja prema znanstvenim disciplinama, potvrđujući intuitivna očekivanja o njihovim diskursnim preferencijama. Naime, empirijski usmjerene discipline, poput kemije, medicine, psihologije ili strojarstva, koje se temelje na laboratorijskim mjerenjima ili eksperimentalnom pristupu, retorički konstruiraju dojam nepristranosti isticanjem istraživačkih metoda i postupaka. S druge strane, u radovima iz područja humanistike, i to osobito književnosti, naglašava se perspektiva znanja preuzetog od autoriteta s ciljem stvaranja kritičke interakcije i pokušaja usustavljivanja u lepezi supostavljenih svjetonazorskih viđenja. U odnosu na kontrastno istraživanje različitih jezika autorica zaključuje da je hrvatski znanstveni diskurz obilježen neosobnom perspektivnom izvješćivanja dok se u engleskome slobodnije koristi osobna perspektiva 1 . lica jednine. Takav kontrastni pristup uspio je istaknuti zajedničke pragmatičke funkcije dokazivanja i uvjeravanja u znanstvenom diskurzu, ali i ukazati na različita sredstva i retoričke prakse svojstvene različitoj prirodi istraživačkih procesa i kulturnih uvjerenja pojedinih disciplina i znanstvenih zajednica.

Knjiga predstavlja izniman doprinos pregledu pojmova jezične epistemologije, stjecanju i prenošenju znanja općenito, a jedinstvena je na području rasprava o strategijama iskazivanja znanstvenog diskurza širinom teorijskog pregleda, relevantne literature i opsegom obrađenog korpusa i kvalitativne empirijske analize. U tome pogledu vjerujem da će se naći na popisu literature u obrazovnim programima koji se bave izobrazbom mladih znanstvenika. Osobito je značajna perspektiva kritičkog promišljanja znanstvenog diskurza koju Ivana Bašić svojim sustavnim 
tumačenjem u ovoj knjizi otvara. Znanost kao ljudski poduhvat akumulacije i promicanja znanja ne počiva samo na promicanju jedne, već na umreženju različitih vrsta spoznavanja stvarnosti u smislenu cjelinu; na onome što se u znanstvenim krugovima naziva inter-/multi-/trans-disciplinarnošću. Međutim, upravo ova knjiga svjedoči o mogućim teškoćama pothvata takva umrežavanja, jer bez jasnog uvida u različitosti konstrukcije znanja postoji opasnost da se različitost tumači kao isključivi, a ne komplementarni sastojak složenosti tvarno-psihološke-društvene stvarnosti. Nadajmo se da će ova knjiga doprinijeti ne samo stručnijoj uporabi retoričkih sredstava u izvješćivanju o rezultatima znanstvenog rada, već i cjelovitijem razumijevanju procesa znanstvene spoznaje.

\section{Reference}

Bašić, I. (2017). Glagoli izvješćivanja kao nositelji dokaznosti u tekstovima znanstvenih radova na engleskome i hrvatskome jeziku (Doctoral dissertation).

Bašić, I. (2020). Dokazivanje i odnos prema znanju u jeziku znanosti. Zagreb: Hrvatska sveučilišna naklada.

Givón, T. (1982). Evidentiality and epistemic space. Studies in Language. International Journal sponsored by the Foundation "Foundations of Language", 6(1), 23-49.

Gnjatović, T., i Matasović, R. (2010). Evidencijalne strategije u hrvatskom jeziku. Zbornik radova znanstvenoga skupa s međunarodnim sudjelovanjem, Drugi hrvatski sintaktički dani, 89-99.

Thompson, G., \& Yiyun, Y. (1991). Evaluation in the reporting verbs used in academic papers. Applied linguistics, 12(4), 365-382.

Benedikt Perak 